\title{
A Typology of Conventions
}

We must notice that the illocutionary act is a conventional act: an act done as conforming to a convention.

-J. L. Austin, How to Do Things with Words

But for every convention in the hand, there are two in the bush.

-A. R. Louch, Explanation and Human Action

Since communication is only one kind of human activity accounted for by conventions, we can ask how communicative conventions relate to other conventions of social action. Exactly which conventions are relevant to reading and interpretation? Do the communicative conventions for speech acts and literary reading function in the same way in textual interpretation? To answer these questions, I will broaden my analysis and provide a general typology of conventions. The subsequent chapter will propose a comprehensive theory of interpretive conventions.

\section{Kinds of Shared Practices}

The term "convention" has been used in a variety of ways across several areas of study, including sociology, linguistic pragmatics, philosophy of language, social psychology, cultural anthropology, and literary criticism. Understood in its widest application, "conventions" refers to shared practices. The following schema distinguishes the three kinds of conventions relevant to the study of human action.

(i) Traditional conventions of precedent: working definition-descriptions recognizing (past) regularities in action and belief 
representative terms - custom and ritual examples-singing the national anthem before a football game

central ritual of organized religion (such as the Mass of Roman Catholicism)

genre and mode in literature

(ii) Regulative conventions of agreement or stipulation:

working definition-prescriptions regulating (future) action

representative terms-covenant and law

examples-football rules for penalties

central covenant of organized religion (such as

the Mosaic Law of Judaism)

propriety or censorship in literature

(iii) Constitutive conventions of meaning:

working definition-descriptions determining (present) meaning

representative terms-systems constituting meaning

examples-football rules constituting a touchdown

systems of religious belief constituting sacrifices

communicative competence constituting

speech acts

Traditional conventions are based on precedent and manifested most explicitly in a society's customs and rituals. ${ }^{1}$ For example, singing the national anthem before a sports event is a traditional convention in contemporary American society. David Lewis's definition of conventions in general applies to these traditional conventions of precedent: "Conventions are regularities in action, or in action and belief, which are arbitrary but perpetuate themselves because they serve some common interest. Past conformity breeds future conformity because it gives one a reason to go on conforming; but there is some alternative regu-

1. "Custom" refers to habitual action or expected behavior. Ritual is "a category of standardized behaviour (custom) in which the relationship between the means and the end is not 'intrinsic,' i.e. is either irrational or non-rational"; some other custom could easily have been used to fulfill the ritual's function, becoming the traditional convention in force-see Jack Goody, "Religion and Ritual: The Definitional Problem," British Journal of Sociology, 12 (1961), 159. Obviously, as traditional conventions become more formalized (as in religious rites) they come to resemble regulative conventions prescribing behavior. 
larity which could have served instead, and would have perpetuated itself in the same way if only it got started." 2 Such conventions can loosely be translated into descriptive "rules" that account for conventional behavior and belief. ${ }^{3}$ These rules or conditions make the content of the conventions explicit. For instance, we might describe the sequence of actions that make up a certain traditional ritual: Just before an American football game, the announcer asks the audience to stand; the audience stands; the band begins to play; etc.

A series of contrastive pairs suggests the basic difference between traditional and regulative conventions: descriptive vs. prescriptive, normal vs. normative, habitual vs. prescribed, regular vs. regulated, expected vs. obligatory. Traditional conventions easily "rigidify" into regulative conventions: we have always done it this way (a description), therefore we should continue to do it this way (a prescription). ${ }^{4}$ The history of standing up for the national anthem is an example of this transformation pro-

2. David Lewis, "Languages and Language," in Language, Mind, and Knowl$e d g e$, ed. Keith Gunderson (Minneapolis: University of Minnesota Press, 1975), pp. 4-5; for a more complete account of this kind of convention, see pp. 5-6, and also Lewis's earlier discussions in his Convention: A Philosophical Study (Cambridge: Harvard University Press, 1969). Cf. Stephen R. Schiffer, Meaning (London: Oxford University Press, 1972), especially pp. 148-55; pp. 129-30 of Schiffer's book suggested the terms "precedent" and "agreement (or stipulation)" in my typology of conventions. Traditional conventions are similar to what Bach and Harnish call "social regularities," which they define as a kind of behavior $A$ fulfilling two conditions: (i) the members of a collectivity do $A$ in certain recurrent situations; and (ii) it is mutually believed among these members that (i)--see Kent Bach and Robert M. Harnish, Linguistic Communication and Speech Acts (Cambridge: MIT Press, 1979), p. 272.

3. The term "rules," for all its misleading associations, does capture the sense of order that conventions establish as the ground for intelligibility, the basis of any theory of interpretive conventions of the kind I will propose based on this chapter's typology. See Lewis's discussion of rules ("an especially messy cluster concept") in Conventions, pp. 100-107; also see Hubert Dreyfus on orderly-butnot-rule-governed behavior in What Computers Can't Do: The Limits of Artficial Intelligence, 2d ed. (New York: Harper \& Row, 1979), esp. pp. 271 and 286-87.

4. By "prescriptions" I mean to include proscriptions against doing something (negative prescriptions) as well as positive prescriptions to do something. Regulative or prescriptive conventions are "sanctioned norms" that of ten include "collective evaluations" of what behavior ought to be-see Jack P. Gibbs, "Norms: The Problem of Definition and Classification," American Journal of Sociology, $7^{\circ}$ $\left(19^{6} 5\right), 5^{89-93}$. Also, $\mathrm{cf}$. the legal discussion of prescriptive rules in William Twining and David Miers, How To Do Things With Rules (London: Weidenfeld and Nicolson, 1976), esp. pp. $4^{8-70 .}$ 
cess in which a traditional custom becomes a binding practice. ${ }^{5}$ Prescriptive conventions as rules regulating future actions are most formally manifested in covenants and laws. A simple illustration is rules for penalties in football, formal rules of behavior for which all players agree to be held accountable.

In contrast to prescriptive rules for penalties, there are descriptive rules that constitute a touchdown in American football. These constitutive conventions describe the conditions under which a certain action has meaning. John Searle has usefully contrasted the "regulative rules" of etiquette (regulative conventions) with the "constitutive rules" of achieving checkmate or making a touchdown (constitutive conventions). ${ }^{6}$ "Constitutive rules do not merely regulate, they create or define new forms of behavior." Without such constitutive conventions it would be impossible to make a touchdown, whereas without the regulative conventions of etiquette it would still be possible to eat mashed potatoes with your hands. "Constitutive rules often have the form: $X$ counts as $Y$ in context $C$." 8 Through a system of constitutive conventions, a football player's crossing of a certain line with a certain object counts as a touchdown. One pervasive set of constitutive conventions is that of language use, a system of conventions making speech acts possible. ${ }^{9}$

5. In 1923 and 1924 , national flag conferences in Washington, D.C., drew up a code "prescribing the correct manner of displaying and respecting the flag. In 1942, by joint resolution, Congress adopted this code as federal law" (David Eggenberger, Flags of the U.S.A. [New York: Thomas Y. Crowell, 1959], p. 193). The regulative convention formalized into law reads: "When the national anthem is played and the flag is not displayed, all present should stand and face toward the music" (United States Code, 22 June, 1942, ch. 435, sec. 6, $5^{6}$ Stat. 380 ).

6. John R. Searle, Speech Acts: An Essay in the Philosophy of Language (London: Cambridge University Press, 1969), pp. 33-42; see also John Rawls on "rules of practices" in "Two Concepts of Rules," Philosophical Review, 64 (1955), 26 . J. R. Cameron provides a precedent for using the term "constitutive conventions" to refer to what Searle calls "constitutive rules"-see Cameron, "'Ought' and Institutional Obligation," Philosophy, 46 (1971), 311, and "Sentence-Meaning and Speech Acts," Philosophical Quarterly, 20 (1970), 98-99.

7. Searle, Speech Acts, p. 33 .

8. Ibid., p. 35 .

9. For work in speech act theory, see above, Ch. 4, nn. 21 and 22. Also cf. Saussure's comments on the universality of language compared to other social institutions and his discussion of how signification is based on the "arbitrary convention" associating signifier with signified. He writes that "every means of expression used in society is based, in principle, on collective behavior or-what 


\section{Interpretive Conventions}

This account of conventions does not rule on whether all action is conventional, that is, motivated by convention. However, all three kinds of conventions can function as motives: by providing precedents (traditional conventions); by stipulating the rules for action, agreed upon through voluntary covenant or imposed law (regulative conventions); and by describing the conditions under which a certain institutional act counts as such (constitutive conventions). This proposed account of conventions can be applied to a wide range of human activities and within a variety of disciplines. In what follows, I will use the typology to examine the kinds of conventions employed in literary study.

\section{Literary Conventions}

Literary criticism and theory have made wide use of the notion of convention. Literary conventions have most often been viewed as traditional conventions-accepted subjects and forms used by writers and recognized by readers. As traditional conventions, they are "habits of art" which provide compositional possibilities for authors and raise expectations in their audiences. ${ }^{10}$ These conventions of precedent include both modal and generic conventions. Put most succinctly: modes are stylistic and thematic conventions that cross genres; for instance, symbolism, realism, and romanticism are modes that can be manifested in the lyric poem, the historical drama, and the war novel; genres are conventional categories of literary works.

Though studies of individual modes are common, theoretical

amounts to the same thing-convention." Ferdinand de Saussure, Course in General Linguistics, ed. Charles Bally and Albert Sechehaye, trans. Wade Baskin (New York: McGraw-Hill, 1966 ), pp. 67-74; the quotations are from pp. 74 and 68. For a useful history and philosophical analysis of the concept of "conventional meaning," see Bernard E. Rollin, Natural and Conventional Meaning: An Examination of the Distinction (The Hague: Mouton, 1976).

10. See Robert M. Browne, "Theories of Convention in Contemporary American Criticism," Ph.D. diss., Catholic University of America, 1956 (rpt. Folcroft Library Editions, 1971), esp. pp. 12-13. On the concept of convention (especially in literary theory) during earlier periods and in other countries, see Lawrence Manley, Convention, I5OO-I 750 (Cambridge: Harvard University Press, 1980), and Harry Levin, "Notes on Convention," in Perspectives of Criticism, ed. Harry Levin (Cambridge: Harvard University Press, 1950), pp. 55-83. 
treatments of mode in general have been scarce. For Paul Alpers, "mode is the literary manifestation, in a given work, of the writer's and the putative reader's assumptions about man's nature and situation." 11 Guided by such a definition, we might say that modal conventions determine the world view that a reader expects to share (or at least recognize) in the course of his reading within a specific mode. Northrop Frye defines mode as "a conventional power of action assumed about the chief characters in fictional literature." 12 Though at first it seems very different, Frye's definition of mode actually complements Alpers's: the "power of action" assumed about the chief character (Frye's definition) particularizes how "assumptions about man's nature and situation" (Alpers's definition) are expressed in a narrative. For example, in the naturalistic mode, the fact that a character has no power of freely chosen action signifies a deterministic view about man's nature and situation.

As revealing as their definitions are, neither Alpers nor Frye focuses on the conventional nature of modes. In contrast, Douglas Hewitt does emphasize this dimension, but he discusses only one specific mode (realism) within one specific genre (the Victorian novel). Still, some of his remarks have implications for an account of mode in general. For instance, he writes: "By 'realistic'... I refer to a formal convention. Like all conventions it is the result of compromise between various demands. But we often talk as though it is not a convention at all, as though it were a way of presenting a direct picture of a series of typical and lifelike experiences. As soon as we try to define it, however, we realize how many questions we are usually begging-how far we take for granted highly conventional and often highly complex features." ${ }^{13}$ Once we admit, with Hewitt, that modal conventions of realism constitute that mode's verisimilitude, it becomes easier to recognize the conventional nature of all modes.

11. Paul Alpers, "Mode in Narrative Poetry," in To Tell a Story: Narrative Theory and Practice (Los Angeles: Wm. Andrews Clark Memorial Li irary, UCLA, 1973), p. 29 .

12. Northrop Frye, Anatomy of Criticism (Princeton: Princeton University Press, 1957), p. 366; Frye observes there that "modes tend to succeed one another in a historical sequence": myth, romance, high mimetic (most epic and tragedy), low mimetic (most comedy and realistic fiction), and then ironic.

13. Douglas Hewitt, The Approach to Fiction (London: Longman, 1972), p. 47. 


\section{Interpretive Conventions}

Literary theorists have discussed genre conventions much more often than those of mode. ${ }^{14}$ Fredric Jameson typifies a well-established view of genres when he writes that they "are essentially contracts between a writer and his readers; or rather... they are literary institutions, which like the other institutions of social life are based on tacit agreements or contracts." ${ }^{15}$ Past literary practice determines such contracts; that is, genre conventions are traditional. They can be as general as those comprising all narratives, distinguishing such texts only from literary genres like lyric poetry; and genre conventions can be as specific as those constituting the many subgenres or formula fictions. Thus, general narrative conventions (like those described by William Labov for natural narratives) can apply to epics, novels, dramas, short stories, and ballads, while specific conventions distinguish such restricted (sub)genres as the Gothic romance, realistic war story, and detective fiction. ${ }^{16} \mathrm{~A}$ typical description of a genre includes the historical precedents and the relevant conventions. For instance, Wellek and Warren's description of the Gothic novel fixes Horace Walpole's Castle of Otranto $(1764)$ as the first in a long line of tales with several distinguishing conventions: "there is not only a limited and continuous subject matter or thematics, but there is a stock of devices (descriptive-accessory and narrative, e.g., ruined castles, Roman Catholic horrors, mysterious portraits, secret passageways reached through sliding panels; abductions, immurements, pur-

14. See Wolfgang Ruttkowski, Bibliography of the Poetics of Literary Genres for the Student of Literature (Munich: Max Hueber, 1973).

15. Fredric Jameson, "Magical Narratives: Romance as Genre," New Literary History, 7 (1975), 135; cf. René Wellek and Austin Warren, Theory of Literature, 2d ed. (New York: Harcourt, Brace, 1956), p. 216 , and Harry Levin, Gates of Horn (New York: Oxford University Press, 1963), pp. 21-23.

16. Labov's study of oral narratives of personal experience led to the following conclusion about their conventional organization: "A complete narrative begins with an orientation, proceeds to the complicating action, is suspended at the focus of evaluation before the resolution, concludes with the resolution, and returns the listener to the present time with the coda"-William Labov, Language in the Inner City (Philadelphia: University of Pennsylvania Press, 1972), p. 369 . See Mary Louise Pratt's use of these conventional narrative sections in an analysis of literary texts: Toward a Speech Act Theory of Literary Discourse (Bloomington: Indiana University Press, 1977), ch. 2. On subgenres see John G. Cawelti, Adventure, Mystery, and Romance: Formula Stories as Art and Popular Culture (Chicago: University of Chicago Press, 1976). 
suits through lonely forests)." ${ }^{7}$ A writer uses such preestablished genres in composing his work, and the generic conventions determine structural and thematic expectations for the reader.

Traditional literary conventions can also function as regulative conventions which stipulate what should and should not be written (or read). Such prescriptive conventions act as evaluative criteria: they become rules that every "good work of art" should follow. Traditional conventions of genre and mode can rigidify into these regulative conventions; classical and neoclassical insistence on purity of kinds and decorum within genres are examples of this transformation. ${ }^{18}$ Also, regulative literary conventions include rules of propriety: prohibitions against portraying explicit sex, against cursing and blasphemy, and so on. In its crudest form, a prescriptive convention of literature is a form of censorship.

Recent literary theory has discussed constitutive conventions as much as traditional conventions and certainly more than regulative ones. Since constitutive conventions include those that make a text count as literary, it is not surprising that theorists refer to them in the perennial debate over the definition of literature. Some theorists attempt to isolate unique conventions that constitute literary discourse. For instance, Richard Ohmann argues for a speech act definition: "A literary work is a discourse whose sentences lack the illocutionary forces that would normally attach to them. Its illocutionary force is mimetic." ${ }^{19}$ In Ohmann's view, speech act conventions are somehow void in literature; for example, a novelist is not committed to the truth of his assertions. According to Ohmann, literary speech acts are "quasi-speech acts," constituted by conventions that imitate speech act rules of ordinary discourse. We can distinguish literature from nonliterature because literary works consist of these quasi-speech acts. Ohmann's definition ends up sounding like essentialist definitions of literature and is vulnerable to the ob-

17. Wellek and Warren, Theory of Literature, p. 223.

18. See, for example, ibid., p. 22o; and William K. Wimsatt, Jr., and Cleanth Brooks, Literary Criticism: A Short History (New York: Knopf, 1957), pp. 8o-82.

19. Richard Ohmann, "Speech Acts and the Definition of Literature," Philosophy and Rhetoric, 4 (1971), 14; italics in original are deleted here. 


\section{Interpretive Conventions}

jection now routinely raised against them: any "essential characteristics" found in literary language can also be found in nonliterary language, whether rhyme, metaphors, or fictivity. Discussing Ohmann's definition, Mary Louise Pratt notes that fictive speech acts are present not only in literature but in daily discourse as well: in hyperbole, teasing, "kidding around," imitations, hypothetical statements, speculations, plannings, and verbal musings of almost any kind. ${ }^{20}$

To avoid such objections, other theorists focus on the constitutive conventions that are merely necessary to literature; that is, these theorists do not claim that such conventions are the exclusive property of literary discourse. Pratt, for example, rejects the literature/nonliterature distinction insofar as it stands for a difference in essential characteristics between literary and "ordinary" speech. She argues that literature is composed of several characteristics, none of which is unique to literary discourse. For instance, she notes that "processes of selection and elimination play a central role in defining and bringing into being the institution we call Literature" but that texts not generally considered literature also go through a similar conventional process. ${ }^{21}$ Furthermore, for Pratt, the literary speech situation consists as much in a reader applying these conventions to a text's genesis and history as it does in the text actually having that prepared and preselected background: "The essence of literariness or poeticality can be said to reside not in the message but in a particular disposition of speaker and audience with regard to the message, one that is characteristic of the literary speech situation."22 Others have pushed the convention-based definition of literature even further by emptying it of any specific ties to prior speaker intention or intrinsic textual properties. These theorists have argued persuasively that the category of literature is a wholly conventional (not an essentialist) one: literature is defined by what a society has decided to call literary. Literature, in this view, is not a set of characteristics held in common by verbal

20. Pratt, p. 91.

21. Ibid., pp. $117^{-18}$

22. Ibid., p. 87 . 
objects; rather, it is an empty category filled by general conventional agreements within historical communities. ${ }^{23}$

Related to this last approach are those theories that describe the kinds of constitutive conventions underlying the activity of reading in the literary situation. They focus on the question: How do readers and critics make sense of literary texts? As we saw in Chapter 2, Stanley Fish answers this question with "communal interpretive strategies" while Jonathan Culler uses a notion of "reading conventions." I will build on these concepts in the next chapter, where I develop a theory of interpretive conventions. It is possible to combine this focus on interpretive (reading) conventions with an answer to the definitional question. Literature then becomes a conventional frame put around discourse, a frame that brings with it reading conventions for interpreting the framed discourse. ${ }^{24}$ This answer avoids the problems of essentialist definitions by making "literariness" a function of the frame (and the reading conventions it makes available) rather than of unique objective characteristics in the text. This view accounts for the intuition that literary texts must somehow differ significantly from nonliterary texts. They do differ, but the distinction is a result of texts being framed and read differently and not a result of intrinsic differences in language. This fact helps explain how the "same" text (for example, the Bible) can be considered nonliterature in one historical community and literature in another and how new meanings can be "discovered" in a nonliterary text once it is treated as literature.

The proposed definition also remedies a problem with theories such as Culler's that define the institution of literature

23. Cf. Morse Peckham, Man's Rage for Chaos: Biology, Behavior and the Arts (Philadelphia: Chilton, 1965), pp. 68-7o; George Dickie, Art and the Aesthetic: An Institutional Analysis (Ithaca: Cornell University Press, 1974), pp. 30-50; and Stanley E. Fish, "How Ordinary Is Ordinary Language?" New Literary History, 5 (1973), rpt. in Is There a Text in This Class?, pp. 108-9.

24. Cf. Susan Stewart, Nonsense: Aspects of Intertextuality in Folklore and Literature (Baltimore: Johns Hopkins University Press, 1979), p. 28: "Each frame [constructed for language] bears a set of procedures for interpretation that members manipulate in engaging the text." 


\section{Interpretive Conventions}

solely in terms of reading conventions. ${ }^{25}$ For instance, John Reichert effectively argues against Culler's view of literature as a conventional institution by pointing out that the literary reading conventions Culler describes (conventions of significance and unity, for instance) also function in reading nonliterature as nonliterature. Thus he objects to Culler's theory because it does not distinguish the institution of literature from the institution of writing in general. ${ }^{26}$ I would claim instead that it is not just reading conventions that constitute literature; it is the conventional framing of a discourse as literature plus the reading conventions (used vigorously and together) that the framing brings along with it. ${ }^{27}$

This framing takes place within historical communities, a fact that has two important consequences. First, what is framed may change from culture to culture, from period to period, and the hierarchy of reading conventions brought along with the frame may change as certain conventions achieve priority and others lose status. ${ }^{28}$ Second, the successful act of framing is communal, not individual. ${ }^{29}$ The notion of community thus becomes crucial

25. Culler, Structuralist Poetics (Ithaca: Cornell University Press, 1975), pp. 115,118 . In The Structure of Literary Understanding (Cambridge: Cambridge University Press, 1978), Stein Haugom Olsen also focuses on the reading conventions making up the institution of literature (pp. 82-117). However, Olsen gives one convention absolute priority: "to impose some sort of structure on the text, to divide it into parts and to interrelate the parts in a pattern" (p. 82). By giving authority only to this convention of unity, he too narrowly limits the reading conventions relevant to literary interpretation.

26. John Reichert, Making Sense of Literature (Chicago: University of Chicago Press, 1977), pp. ${ }^{155^{-6}}$. Reichert makes a similar objection to Olsen's theory in his review of The Structure of Literary Understanding, Comparative Literature, 32 (1980), $210-13$.

27. It remains an open question how many of Culler's literary reading conventions actually are used in reading texts considered nonliterary. However, my discussion of literary communication in Ch. 4 requires only that there are certain conventions for reading literature, not that they are exclusively those for reading literature.

28. See Morse Peckham, "Literature': Disjunction and Redundancy," in What Is Literature?, ed. Paul Hernadi (Bloomington: Indiana University Press, 1978), pp. 223-24; Frank Kermode, "Institutional Control of Interpretation," Salmagundi, No. 43 (1979), pp. 83-84; and the works cited above, Ch. 2, n. $3^{8}$.

29. Though I have been using the notion of framing to explain how a discourse is placed in the descriptive category of literature, a successful act of framing refers to establishing a discourse as literary either in the descriptive or in the honorific sense. That is, an individual (e.g., author, publisher, literary critic) 
here. In sociology, three aspects characterize the term "community": geographic area, social interaction, and common ties. ${ }^{30}$ In the modern age of rapid communication and transportation, geographic area has become less a distinguishing characteristic of community than social interaction and common ties. But even these latter factors must be reconceived in light of modern technology. Social interaction now takes place over the telephone and television, through rapidly distributed periodicals, and at annual conferences in addition to day-to-day, neighborhood contact. Common ties remain the most relevant general criteria for defining community. For my purposes, common ties can be conceptualized as shared traditions, imposed or agreedupon behavior patterns, and common ways of making sensethat is, as traditional, regulative, and constitutive conventions. ${ }^{31}$ As one sociologist of communities has written, community members 'are in the same 'club' whose conventions constitute a

performs a successful act of framing only when he convinces a community to accept his framing as its own, and that acceptance can take the form either of including the discourse in the general descriptive category of literature or of placing the discourse within the privileged literary canon.

3o. George A. Hillery, Jr., "Definitions of Community: Areas of Agreement," Rural Sociology, 20 (1955), 118-19. Recent discussions continue to take Hillery's analysis as authoritative; see Jessie Bernard, The Sociology of Community (Glenview, Ill.: Scott, Foresman, 1973), pp. 3-5, and Dennis E. Poplin, Communities: $A$ Survey of Theories and Methods of Research, $2 \mathrm{~d}$ ed. (New York: Macmillan, 1979), pp. $3^{-25}$

31. My view of historical communities here can be contrasted to the communities discussed by Bleich and Fish-see above, Ch. 1. First of all, historical communities are more unified, have more conventions in common for longer periods of time, than do Bleich's provisional discussion groups. Second, Fish's interpretive communities refer to only one aspect (though a most important one) of historical communities-shared constitutive conventions for making sense of reality. At particular moments on particular issues, a single historical community can function as a single interpretive community; for example, in $194^{2}$ most citizens of the United States used the same interpretive strategies to make sense of World War II (as a fight for freedom, etc.) and in the mid-nineteenth century a European community of astronomers used the same Copernican paradigm to interpret celestial motion (as a system of planets orbiting around the sun). More often, however, historical communities are made up of several conflicting interpretive communities: in the late 1960 , U.S. citizens had radically different ways of making sense of the Vietnam War and a historical community of the midnineteenth century could include astrologers, Fundamentalist Christians, and Copernican astronomers, all with radically different ways of interpreting the cosmos. 


\section{Interpretive Conventions}

kind of boundary-maintenance device." 32 So understood, historical communities that fill the category of "literature" can be whole societies, but more often they are societal groups based on economic organization (for example, the network of authors, publishers, periodical editors, and book reviewers), social rank (for instance, intelligentsia and governing classes), or institutional and professional position (such as English professor). ${ }^{33}$

We might more fully understand conventions relevant to literary study by looking at the following diagram, which places literary conventions (traditional, regulative, and constitutive) within a larger framework.

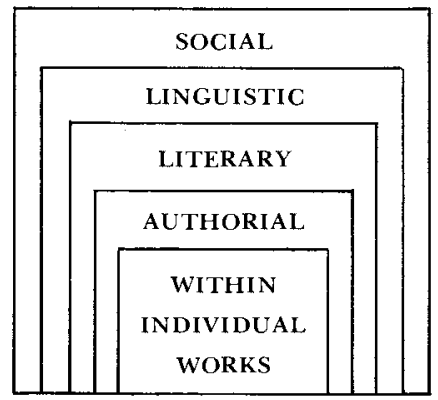

Disciplines such as sociology, social psychology, and cultural anthropology focus on the most general social conventions of human activity. The question "What is art?" can be answered at this level, if art is viewed as a social institution constituted by convention. Language is a social convention with its own set of linguistic conventions: lexigraphic, syntactic, semantic, and pragmatic; the pragmatic component includes the communicative conventions of speech act conditions and conversational postulates. These conventions of language (form and use) are studied in such disciplines as rhetoric, philosophy of language, communication theory, and linguistics (including sociolinguistics, psycholinguistics, ethnography of speaking, and others). I have

32. Bernard, p. 9 .

33. Cf. Dickie, pp. $3^{1-38}$; Richard Ohmann, "The Social Definition of Literature," in Hernadi, pp. 89-101; and William J. Goode, "Community Within a Community: The Professions," American Sociological Review, 22 (1957), $194^{-200 .}$ 
just discussed literary conventions in examining modes and genres. ${ }^{34}$ This level isolates the specific conventions for reading literature. A writer develops authorial conventions throughout the works making up his literary corpus. Examples range from characteristic word usages and individual symbolic systems to idiosyncratic plot or image patterns to particular variations on generic and modal conventions.

We may also speak of conventions developed within individual works. It might at first seem unsatisfying to refer to a "convention" established during the reading of a single literary text. Like genre conventions, however, conventions within a work are agreements or contracts set up between reader and author; they are the "ground rules" for that particular work and include provisions for allowable characters (hobbits or dentists), permissible narrator knowledge or intrusion (omniscient or limited points of view), possible plot twists (supernatural intervention or realistic cause-and-effect), and requirements of an implied reader. Specific conventions vary in different texts, but, as Douglas Hewitt writes, "what we do demand is consistency to its convention within each work." ${ }^{35}$ Readers sometimes recognize such conventions immediately at the beginning of a narrative; in other cases they are learned slowly during the reading experience. For example, in my analysis of "Rappaccini's Daughter" in Chapter 3, I demonstrate how Hawthorne's discourse strategies teach the reader certain conventions of judgment that Hawthorne relies on the reader to use in making the final ethical judgment required by the narrative's ending.

With this typology of conventions and the various definitions of genre, mode, and so forth as background, I can now propose a comprehensive theory of interpretive conventions. The payoff for all this hermeneutic wind-up will be a detailed examination of the disguised interpretive work within American literary history.

34. For an especially interesting comparison between the levels of social and literary conventions, see Elizabeth Burns's discussion of the "rhetorical" and "authenticating" conventions of the theatre-in Theatricality: A Study of Convention in the Theatre and in Social Life (New York: Harper \& Row, 1972), chs. 4-7.

35. Hewitt, p. $5^{8}$. 